\title{
Distribution of Hoplolaimus Species in Soybean Fields in South Carolina and North Carolina
}

Claudia M. Holguin and Xinyuan Ma, Department of Agricultural and Environmental Sciences, Clemson University, Clemson, SC 29634; John D. Mueller, Edisto Research and Education Center, Clemson University, Blackville, SC 29817; and Paula Agudelo, Department of Agricultural and Environmental Sciences, Clemson University, Clemson

\begin{abstract}
Holguin, C. M., Ma, X., Mueller, J. D., and Agudelo, P. 2016. Distribution of Hoplolaimus species in soybean fields in South Carolina and North Carolina. Plant Dis. 100:149-153.

Hoplolaimus columbus is an important nematode pest of soybean in South Carolina and North Carolina. Tolerant cultivars are available for the management of this plant-parasitic nematode; however, variation in the response of soybean cultivars to $H$. columbus populations has been observed. This variation may be due to the presence of different species or high genetic diversity of $H$. columbus populations. The objective of this study was to identify the Hoplolaimus spp. present in fields representing the main soybean-growing regions in South Carolina and North Carolina and to examine the genetic variability of these populations. In

South Carolina, the only species found associated with soybean was $H$. columbus but, in North Carolina, H. stephanus was the dominant species. The two species were never found together. Genetic variability analyses of a mitochondrial and a nuclear marker showed that only one haplotype was shared by the $H$. columbus populations. H. stephanus showed higher genetic variability, with private haplotypes per sampling location. Knowledge of the distribution and genetic variability of these two Hoplolaimus spp. is valuable to growers to determine potentially damaging infestations of these plant-parasitic nematodes in soybean fields.
\end{abstract}

Lance nematodes (Hoplolaimus spp.) are migratory ecto-endo plant parasites widely distributed in the United States that feed on the roots of several field crop, grass, and tree species. In the southeastern United States, seven species have been reported (Koenning et al. 1999; Lewis and Fassuliotis 1982; Robbins 1982): Hoplolaimus galeatus (Cobb, 1913) Thorne, 1935, H. columbus Sher, 1963, H. magnistylus Robbins, 1982, H. stephanus Sher, 1963, H. seinhorsti Luc, 1958, H. tylenchiformis von Daday, 1905 (Lewis and Fassuliotis 1982), and $H$. concaudajuvencus Golden and Minton, 1970. Of these, only H. columbus, H. galeatus, and H. magnistylus have been reported to be of economic importance on soybean (Glycine max) (Fassuliotis 1974; Noe 1993; Nyczepir and Lewis 1979).

$H$. columbus (Columbia lance nematode) was first described from soybean in Richland County, SC (Sher 1963). Since that time, $H$. columbus has been mainly found in South Carolina, North Carolina, and Georgia (Koenning et al. 1999; Lewis and Fassuliotis 1982), with one report from Alabama (Gazaway and Armstrong 1994) and one from Louisiana (Astudillo and Birchfield 1980). In South Carolina and North Carolina, H. columbus is primarily associated with cotton and soybean, on which pathogenicity has been demonstrated (Appel and Lewis 1984; Lewis et al. 1976; Mueller and Sanders 1987). Losses on cotton are typically 10 to $25 \%$, and losses on soybean can be as high as $70 \%$ (Mueller and Sanders 1987; Noe 1993). In Alabama, Arkansas, Mississippi, and Tennessee, $H$. galeatus has been found associated with cotton and soybean (Koenning et al. 1999; Lewis and Fassuliotis 1982; RodríguezKábana and Thurlow 1980) but, in Florida and South Carolina, $H$. galeatus is commonly reported causing damage on grasses (Henn and Dunn 1989; Kinloch and Sprenkel 1994; Lewis and Fassuliotis 1982). H. magnistylus was first detected in soil around soybean roots in Arkansas and Mississippi (Robbins 1982) and has also been found on corn and cotton in Tennessee and Illinois (Donald

Corresponding author: Paula Agudelo,

E-mail address: pagudel@clemson.edu

Accepted for publication 22 June 2015.

http://dx.doi.org/10.1094/PDIS-12-14-1332-RE

(C) 2016 The American Phytopathological Society et al. 2013) but this species has not been reported in South Carolina and North Carolina.

Management of nematodes in soybean includes the use of resistant and tolerant cultivars (Appel and Lewis 1984; Koenning et al. 2004; Lewis et al. 1976; Mueller and Sanders 1987; Mueller et al. 1988). For $H$. columbus, tolerant soybean cultivars are a plausible management option (Mueller et al. 1988; Schmitt and Imbriani 1987). However, variation in the response of soybean cultivars to $H$. columbus populations has been observed (Koenning et al. 2004; Mueller and Sanders 1987; Mueller et al. 1988; Nyczepir and Lewis 1979), and it is possible that this variation in response is due to the presence of different Hoplolaimus spp. or high genetic diversity among $H$. columbus populations. Bae et al. (2009b) studied the genetic variability of $H$. columbus, including several populations from soybean, using DNA sequences of the internal transcribed spacer (ITS)1-5.8S-ITS2 ribosomal DNA (rDNA). In this study, genetic clonal diversity within $\mathrm{H}$. columbus individuals was found; however, differences among populations were not detected.

No comprehensive survey of Hoplolaimus spp. associated with soybean has been undertaken. Knowledge of the species and genetic diversity of Hoplolaimus spp. present in soybean fields may help in understanding evolutionary processes of populations, such as development of races and adaptation to selection pressures. Additionally, it may provide insights to the effective use of resistant and tolerant cultivars as a management strategy for this plant-parasitic nematode (Gutiérrez-Gutiérrez et al. 2011; Plantard and Porte 2004).

The objectives of this study were to (i) identify Hoplolaimus spp. found in the main soybean-growing regions in South Carolina and North Carolina (the states where $H$. columbus is most frequently reported) and (ii) use mitochondrial DNA (cytochrome $c$ oxidase subunit I [COI]) and nuclear (ITS1) sequence data to study the genetic structure and haplotype diversity of the populations recovered.

\section{Materials and Methods}

Sampling. Samples were collected in 2012 as part of a larger study conducted to determine the distribution of plant-parasitic nematode genera associated with soybean in the southeastern United States. Soil samples were collected from 100 fields in North Carolina, representing 44 counties, and 95 fields in South Carolina, representing 15 counties (Fig. 1 and Table 1). The number of samples collected per county was based on the soybean area planted, and farms within 
each county were selected arbitrarily. One field was represented by a single sample composed of 5 to 10 subsamples of $200 \mathrm{~cm}^{3}$ collected from within rows in a zigzag pattern. All samples were collected after harvest, between October and December. Nematodes were extracted from the soil using the sugar centrifugal flotation method (Jenkins 1964) and identified to genus on the basis of morphology. Specimens identified as genus Hoplolaimus were counted and identified to species using the original descriptions of the species (Sher 1963) and the key by Handoo and Golden (1992).

Additional samples included in this study in order to compare genetic variability were one sample from a soybean field in Pierce County, GA and one sample from corn (Zea mays); and one from sorghum (Sorghum bicolor) and three from cotton (Gossypium hirsutum) from South Carolina.

DNA extraction, polymerase chain reaction amplification, and sequencing. DNA was extracted from single adult nematodes from each Hoplolaimus population. The number of individuals analyzed per population varied depending on the number of nematodes found in each soil sample. DNA extraction was performed using the Sigma Extract-N-Amp kit (XNAT2; Sigma-Aldrich, St. Louis), as reported by Ma et al. (2011). DNA was stored at $-20^{\circ} \mathrm{C}$ until used.

ITS1 was amplified with primers Hoc-1f (5'-AACCTGCTGCTG GATCATTA-3') and LSUD3r (5'-TATGCTTAAGTTCAGCGGGT$3^{\prime}$ ) following Bae et al. (2009a). A portion of the mitochondrial COI was amplified using primers JB3 $\left(5^{\prime}\right.$ TTTTTTGGGCATCCTGAGGTT TAT 3') and JB5 (5' AGCACCTAAACTTAAAACATAATG-AAA 3') (Derycke et al. 2005). For COI, the initial denaturation was set at $95^{\circ} \mathrm{C}$ for $3 \mathrm{~min}$; followed by 33 cycles of $95^{\circ} \mathrm{C}$ for $45 \mathrm{~s}, 50^{\circ} \mathrm{C}$ for $1 \mathrm{~min}$ $15 \mathrm{~s}$, and $72^{\circ} \mathrm{C}$ for $2 \mathrm{~min}$; and final extension at $72^{\circ} \mathrm{C}$ for $10 \mathrm{~min}$. The amplified products were loaded onto a $1.5 \%$ agarose gel and visualized using GelRed (Biotium, San Francisco, CA). polymerase chain reaction (PCR) products for both regions were purified using magnetic beads and sequenced in both directions with the ABI 3730 capillary sequencer (Applied Biosystems, Grand Island, NY) in the DNA Laboratory at Arizona State University.

Sequence alignment. For the two loci, contigs were edited and assembled in Sequencher 5.1 (Genes Code Corp., Ann Arbor, MI) and consensus DNA sequences then were aligned using ClustalW (Thompson et al. 1997). In the ITS original alignment, several indels were detected. Therefore, divergent and ambiguously aligned positions were removed and conserved blocks selected using the software Gblocks v0.91b (Castresana 2000) with default values. Unique haplotypes for mitochondrial and nuclear markers were deposited in GenBank (Tables 2 and 3).

Molecular analysis. The best substitution model (Generalized Time-Reversible) was identified for COI and ITS fragments using the Akaike Information Criterion in the software Modeltest v.3.7 (Posada and Crandall 1998). For populations from which more

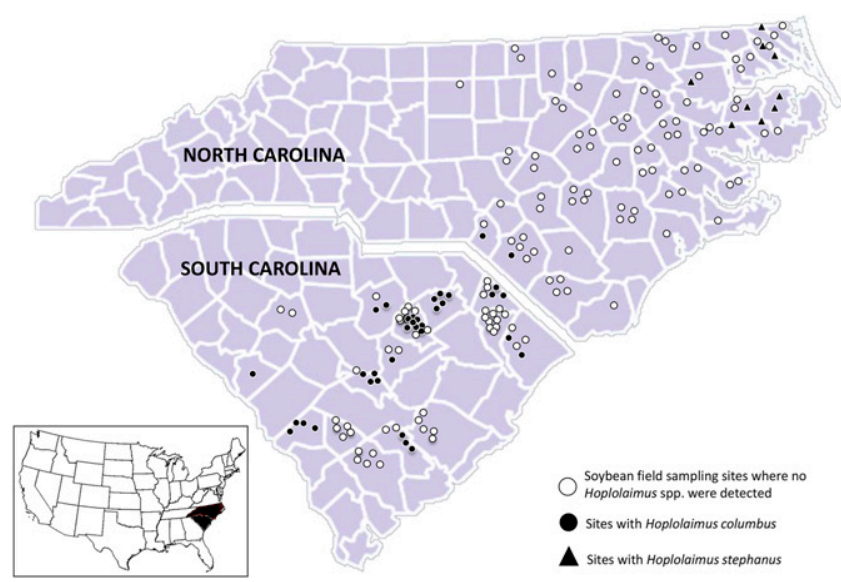

Fig. 1. Locations of soybean fields included in a survey to determine the occurrence and distribution of Hoplolaimus spp. in North Carolina and South Carolina. than one individual was available, diversity statistics for both loci were calculated using the software DNAsp (Librado and Rozas 2009). To estimate genetic differentiation among populations within each species, pairwise $\Phi_{\text {ST }}$ values were calculated using the Timura and Nei model in Arlequin v. 3.11 (Excoffier et al. 2005). For the mitochondrial COI region, to assess variance among populations within and between each Hoplolaimus sp., an analysis of molecular variance (AMOVA) was conducted in Arlequin v. 3.11 (Excoffier et al. 2005). Statistical significance was tested with 10,000 permutations. Unrooted haplotype networks

Table 1. Species of Hoplolaimus found in North Carolina and South Carolina in this study

\begin{tabular}{|c|c|c|c|c|}
\hline Counties & Species & $\begin{array}{l}\text { Number } \\
\text { of fields } \\
\text { sampled }\end{array}$ & $\begin{array}{c}\text { Number of } \\
\text { fields with } \\
\text { Hoplolaimus } \\
\text { spp. }\end{array}$ & $\begin{array}{c}\text { Min-Max } \\
\text { (individuals/10 }^{\text {Mef }} \\
\mathbf{c m}^{3} \text { of soil) }\end{array}$ \\
\hline \multicolumn{5}{|l|}{ North Carolina } \\
\hline Bertie & $\begin{array}{c}\text { Hoplolaimus } \\
\text { stephanus }\end{array}$ & 2 & 1 & 60 \\
\hline Camden & H. stephanus & 2 & 1 & 50 \\
\hline Pasquotank & H. stephanus & 4 & 2 & 20 \\
\hline Tyrrell & H. stephanus & 3 & 2 & $10-40$ \\
\hline Washington & H. stephanus & 3 & 1 & 70 \\
\hline Beaufort & H. stephanus & 4 & 1 & 20 \\
\hline Scotland & H. columbus & 2 & 1 & 30 \\
\hline Robeson & H. columbus & 6 & 1 & 20 \\
\hline \multicolumn{5}{|c|}{ South Carolina } \\
\hline Lee & H. columbus & 31 & 12 & $10-70$ \\
\hline Sumter & H. columbus & 3 & 1 & 50 \\
\hline Kershaw & H. columbus & 3 & 2 & $60-80$ \\
\hline Calhoun & H. columbus & 5 & 4 & $30-230$ \\
\hline Barnwell & H. columbus & 4 & 4 & $20-150$ \\
\hline Dorchester & H. columbus & 5 & 3 & $20-130$ \\
\hline Edgefield & H. columbus & 1 & 1 & 50 \\
\hline Horry & H. columbus & 5 & 2 & 10 \\
\hline Dillon & H. columbus & 6 & 3 & $10-30$ \\
\hline Darlington & H. columbus & 5 & 5 & $10-30$ \\
\hline
\end{tabular}

a Minimum and maximum densities (individuals $/ 100 \mathrm{~cm}^{3}$ of soil) of lance nematode species found. Single values provided when only one field with lance species was detected per county or equal values were found for all fields.

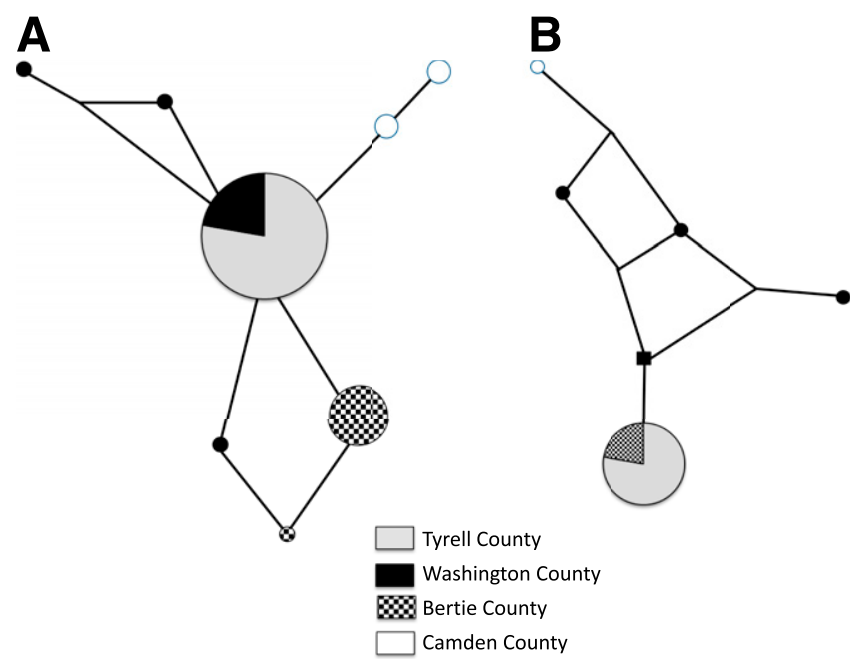

Fig. 2. Median-joining haplotype networks for four populations of Hoplolaimus stephanus collected from North Carolina and South Carolina. A, Sequence variation in cytochrome $c$ oxidase subunit I mtDNA region. B, Sequence variation in internal transcribed spacer region, Length of the branch represents one mutational difference. Size circles are proportional to the number of individuals sharing the same haplotype, with the smallest circle representing one haplotype copy. 
were also constructed using median joining in the software SplitsTree4 (Huson and Bryant 2006).

\section{Results}

Of the 100 soybean fields sampled in North Carolina, Hoplolaimus individuals were only detected in 10 fields distributed in eight counties. The predominant species in North Carolina was H. stephanus, identified in the six counties Beaufort, Bertie, Camden, Pasquotank, Tyrrell, and Washington (Fig. 1). H. columbus was only detected in two fields in North Carolina, one in Scotland County, and one in Robeson County. Densities of H. stephanus in North Carolina ranged from 10 to 70 individuals per $100 \mathrm{~cm}^{3}$ of soil while densities of $H$. columbus ranged from 20 to 30 individuals per $100 \mathrm{~cm}^{3}$ of soil (Table 1). In South Carolina, H. columbus was the only species found, and was present in 37 of 95 fields, distributed in the 10 counties: Barnwell, Calhoun, Darlington, Dillon, Dorchester, Edgefield, Horry, Kershaw, Lee, and Sumter, (Fig. 1; Table 1). The highest densities of $H$. columbus were detected in Barnwell, Calhoun, and Dorchester Counties (Table 1). For the five additional fields sampled in South Carolina (corn, sorghum, and cotton) and the soybean field in Georgia, the species identified was also H. columbus. The two species were never found present together in the same field.
Genetic population structure. A total of $387 \mathrm{bp}$ of the COI gene was screened for $22 \mathrm{H}$. stephanus individuals, which constitute the first COI data available for the genus in GenBank. Most individuals in each population possessed unique mitochondrial haplotypes leading to high diversity for this species (eight haplotypes in total). A single haplotype was shared between populations collected in Tyrrell and Washington Counties, NC (Fig. 2). The most variable population was collected in Washington County, with four haplotypes. Values of haplotype and nucleotide diversity were 0.9 and 0.029 , respectively (Table 2). For $H$. columbus, in total, 56 individuals from soybean and 41 individuals from other field crops were analyzed using a 446-bp fragment of the COI gene (Table 3). Variation was not detected for this segment of COI for all individuals collected from soybean fields in South Carolina, yielding a unique mitochondrial haplotype. A different haplotype was detected in the population collected in Georgia (Table 3 ). From the populations of $H$. columbus collected from other row crops, one population collected in sorghum from Barnwell County had a different haplotype on a single individual (Table 3 ).

For the ITS region, the final alignment consisted of a 913-bp fragment. For this fragment, fewer individuals were examined per population due to the failure of the primers to amplify for several individuals. For H. stephanus, this region showed less variability

Table 2. Sample size $(n)$, number of haplotypes $(h)$, haplotype diversity $(\mathrm{Hd})$, and nucleotide diversity $(\pi)$ for populations of Hoplolaimus stephanus collected from soybean fields in North Carolina

\begin{tabular}{|c|c|c|c|c|c|}
\hline Locus, location & Accession numbers & $n$ & $\boldsymbol{h}$ & Hd & $\pi$ \\
\hline \multicolumn{6}{|c|}{ Cytochrome $c$ oxidase subunit I } \\
\hline Tyrrell County & KP230605-KР230611 & 7 & 1 & 0.00 & 0.0000 \\
\hline Washington County & KP230612-KР230616 & 5 & 4 & 0.90 & 0.0290 \\
\hline Bertie County & KP230596-KP230599 & 5 & 2 & 0.67 & 0.0040 \\
\hline Camden County & KP230600-KP230604 & 5 & 2 & 0.40 & 0.0010 \\
\hline \multicolumn{6}{|l|}{ ITS } \\
\hline Tyrrell County & КР303652-KР303656 & 5 & 1 & 0.00 & 0.0000 \\
\hline Washington County & KP303657-KP303659 & 2 & 1 & 0.00 & 0.0000 \\
\hline Bertie County & KP303647-KP303648 & 1 & 1 & $\ldots$ & $\ldots$ \\
\hline Camden County & KP303649-KP303651 & 3 & 3 & 1.00 & 0.0125 \\
\hline
\end{tabular}

Table 3. Sample size $(n)$, number of haplotypes $(h)$, haplotype diversity (Hd), and nucleotide diversity $(\pi)$ for Hoplolaimus columbus collected in fields in South Carolina, North Carolina, and Georgia

\begin{tabular}{|c|c|c|c|c|c|c|}
\hline Locus, location $^{\text {a }}$ & Host & Accession numbers & $n$ & $h$ & Hd & $\pi$ \\
\hline \multicolumn{7}{|l|}{$\overline{\mathrm{COI}}$} \\
\hline Lee County, SC & Glycine max & KP864605-KP864608 & 10 & 1 & 0.00 & 0.0000 \\
\hline Barnwell County, SC & G. $\max$ & KP864612-KP864614 & 7 & 1 & 0.00 & 0.0000 \\
\hline Barnwell County, SC & G. $\max$ & KP864615-KP864617 & 6 & 1 & 0.00 & 0.0000 \\
\hline Dorchester County, SC & G. $\max$ & KP864618-KP864620 & 6 & 1 & 0.00 & 0.0000 \\
\hline Dorchester County, SC & G. $\max$ & KP864621-KP864622 & 6 & 1 & 0.00 & 0.0000 \\
\hline Pierce County, GA & G. $\max$ & KP864609-KP864611 & 3 & 2 & 0.67 & 0.0020 \\
\hline Calhoun County, SC & Gossypium hirsutum & KP864623-KP864631 & 16 & 1 & 0.00 & 0.0000 \\
\hline Bamberg County, SC & G. hirsutum & КР864596-KР864599 & 9 & 1 & 0.00 & 0.0000 \\
\hline Lee County, SC & G. hirsutum & КP864600-KР864603 & 10 & 1 & 0.00 & 0.0000 \\
\hline Barnwell County, SC & Sorghum bicolor & KP864583-KP864595 & 13 & 2 & 0.15 & 0.0005 \\
\hline Lee County, SC & Zea mays & KP864604 & 5 & 1 & 0.00 & 0.0000 \\
\hline \multicolumn{7}{|l|}{ ITS } \\
\hline Lee County, SC & Glycine $\max$ & KP835328-KP835332 & 15 & 1 & 0.00 & 0.0000 \\
\hline Barnwell County, SC & G. $\max$ & KP835335-KP835337 & 8 & 1 & 0.00 & 0.0000 \\
\hline Barnwell County, SC & G. $\max$ & KP835338 & 1 & 1 & 0.00 & 0.0000 \\
\hline Dorchester County, SC & G. $\max$ & KP835339 & 1 & 1 & 0.00 & 0.0000 \\
\hline Pierce County, GA & G. $\max$ & KP835333 & 1 & 1 & 0.00 & 0.0000 \\
\hline Scotland County, GA & G. $\max$ & KP835334 & 1 & 1 & 0.00 & 0.0000 \\
\hline Calhoun County, SC & Gossypium hirsutum & KP835340-KP835341 & 4 & 1 & 1.00 & 1.0000 \\
\hline Bamberg County, SC & G. hirsutum & KP835319-KP835320 & 5 & 1 & 0.00 & 0.0000 \\
\hline Lee County, SC & G. hirsutum & KP835322-KP835324 & 11 & 1 & 0.00 & 0.0000 \\
\hline Barnwell County, SC & S. bicolor & KP835314-KP835318 & 13 & 1 & 0.00 & 0.0000 \\
\hline Lee County, SC & Z. mays & KP835325-KP835327 & 9 & 1 & 0.00 & 0.0000 \\
\hline
\end{tabular}

${ }^{\text {a }} \mathrm{COI}=$ cytochrome $c$ oxidase subunit I and ITS $=$ internal transcribed spacer. 
in comparison with COI, yielding five haplotypes. However, the majority of the populations contained single haplotypes, and only one haplotype was shared by several populations (Fig. 2). The population with the most variation within this locus was collected in Camden County, with three haplotypes and high haplotype and nucleotide diversity (Table 1 ). For $H$. columbus and the COI region, all sequences from South Carolina populations corresponded to a unique ITS haplotype. Sequences from Georgia and North Carolina populations yielded single different haplotypes each (Table 3 ).

For COI, the population differentiation using the fixation index $\left(\Phi_{\mathrm{ST}}\right)$ was significant for all pairs in $H$. stephanus populations. For ITS, $\Phi_{\text {ST }}$ was only significant between the Camden and Washington County populations (Table 4 ). For $H$. columbus, as expected, differences were only detected between Georgia and South Carolina populations for COI, and between Georgia and North Carolina populations for ITS, with values equal to 1 for ITS (Table 5). Results from the AMOVA for $H$. columbus showed low genetic structure $\left(\Phi_{\mathrm{ST}}=0.27, P=0.035\right)$. When AMOVA was performed per host plant, high and significant fixation index $\left(\Phi_{\mathrm{ST}}=0.98, P<0.0001\right)$ was detected. Variation between host plants explained $96.48 \%$ of the variability, while variation within species and within populations was very low (1.62 and 1.90\%, respectively).

\section{Discussion}

$H$. columbus is the lance nematode species commonly found in cotton and soybean production fields in North Carolina and South Carolina (Fassuliotis et al. 1968; Koenning et al. 1999). In this study, we found that $H$. columbus was the only species detected in association with soybean in South Carolina, with 37 fields (39\%) infested and 16 fields (43\%) harboring densities above the damage threshold of 50 individuals $/ 100 \mathrm{~cm}^{3}$ of soil (Lewis et al. 1993). In a survey of plant-parasitic nematodes associated with soybean fields in South Carolina (Lewis et al. 1993), H. columbus was the only lance nematode species identified; this nematode was detected in $14 \%$ of the fields (500 samples), with $44 \%$ of these fields having densities over the damage threshold (Lewis et al. 1993). Based upon our findings, the reported incidence of this species in South Carolina has almost tripled from 1987 to 2014.

In North Carolina, however, H. columbus was found only in two fields and at low population densities. This finding is consistent with Lewis and Fassuliotis (1982), who also found $H$. columbus to be uncommon in this state. The most predominant species of lance nematode that we found associated with soybean in North Carolina was H. stephanus. H. stephanus was first described by Sher (1963) from

Table 4. Cytochrome $c$ oxidase subunit I pairwise values of $\Phi_{\mathrm{ST}}$ (below diagonal) and internal transcribed spacer pairwise values of $\Phi_{\mathrm{ST}}$ (above diagonal) for $H$. stephanus populations ${ }^{\mathrm{a}}$

\begin{tabular}{lcccc}
\hline Population & Camden & Washington & Tyrrell & Bertie \\
\hline Camden County & $\ldots$ & $\mathbf{0 . 6 6 7 3}$ & 1.0000 & 1.0000 \\
Washington County & $\mathbf{0 . 1 5 2 3}$ & $\ldots$ & 0.0421 & 0.0000 \\
Tyrrell County & $\mathbf{0 . 8 6 2 9}$ & $\mathbf{0 . 0 8 0 5}$ & $\ldots$ & 1.0000 \\
Bertie County & $\mathbf{0 . 8 0 9 6}$ & $\mathbf{0 . 2 3 5 8}$ & $\mathbf{0 . 8 4 6 0}$ & $\ldots$ \\
\hline
\end{tabular}

a Numbers in bold indicate statistical significance $(P<0.0001)$. swamp soil collected in Nichols, SC and no type host was provided. The first report of $H$. stephanus in North Carolina was also from an unspecified host in a natural habitat in Raleigh, NC (Vovlas et al. 1991). To our knowledge, ours is the first report of H. stephanus on soybean in North Carolina. The populations found were variable and showed high genetic structure, as indicated by high and significant pairwise $\Phi_{\mathrm{ST}}$ values, and the COI haplotypes were diverse and unique for each location.

Despite the high prevalence of $H$. columbus in soybean fields in South Carolina (37 of 95 fields sampled), populations of this species lacked genetic structure, not only among those collected from soybean fields but also for the additional row crop fields sampled in South Carolina (sorghum, cotton, and corn). Bae et al. (2009b) evaluated the genetic variability of $H$. columbus populations from several states, including South Carolina, using the same nuclear region (ITS) as in our study. They reported variability among clones within individuals and confirmed this genetic variability using PCR restriction fragment length polymorphism, suggesting that there are different ITS types in the genome of $H$. columbus. However, it was not clear from their study whether there was genetic variability among individuals within populations or among populations.

In our study, we included a mitochondrial marker because of the reported higher rate of mutation compared with nuclear sequences (Hugall et al. 1994; Villate et al. 2010). However, the fragment of COI that we amplified did not detect variability among $H$. columbus individuals. This COI fragment has been successfully used to determine the population structure of several marine and plant-parasitic nematodes (Derycke et al. 2005, 2007; Gutiérrez-Gutiérrez et al. 2011; Apolônio Silva de Oliveira et al. 2012), however, for H. columbus populations, it seems that it is not an appropriate marker to identify genetic differences. Weak mitochondrial diversity also has been reported for other plant-parasitic nematodes such as Meloidogyne spp. (Hugall et al. 1994; Humphreys-Pereira and Elling 2013) and Xiphinema spp. (Gutiérrez-Gutiérrez et al. 2011). A marker with higher resolution such as microsatellites or single-nucleotide polymorphisms may be more appropriate to detect differences among $\mathrm{H}$. $\mathrm{co}$ lumbus populations. High exchange of genetic material has been proposed as a cause for the homogeneity among populations for other plant-parasitic nematodes (Humphreys-Pereira and Elling 2013; Villate et al. 2010). It is unclear whether this is the case for H. columbus from South Carolina soybean fields, but it is a possibility. A more likely explanation for the low genetic diversity found in H. columbus in our study is that this species is a recent introduction in South Carolina and there has not been sufficient time for genetic diversity to develop. The low haplotype diversity and sequence variation found are consistent with the pattern of a founder effect, with bottleneck and subsequent quick expansion (Hugall et al. 1994; Plantard and Porte 2004; Villate et al. 2010). For $H$. stephanus, the high haplotype diversity along with the relatively low sequence variability may be indicative of some level of hybridization (Hugall et al. 1994; Plantard and Porte 2004; Villate et al. 2010); however, this is a hypothesis that would have to be tested.

This study provides an update on the status of $H$. columbus and $H$. stephanus populations associated with soybean in North Carolina and South Carolina. It is necessary to undertake studies that will compare the ecology and biology of $H$. stephanus and

Table 5. Cytochrome $c$ oxidase subunit I pairwise values of $\Phi_{\mathrm{ST}}$ (below diagonal) and internal transcribed spacer pairwise values of $\Phi_{\mathrm{ST}}$ (above diagonal) for Hoplolaimus columbus populations

\begin{tabular}{|c|c|c|c|c|c|c|c|}
\hline Population & $\begin{array}{l}\text { Scotland } \\
\text { County, NC }\end{array}$ & $\begin{array}{c}\text { Hobbs } \\
\text { County, GA }\end{array}$ & $\begin{array}{c}\text { Lee } \\
\text { County, SC }\end{array}$ & $\begin{array}{c}\text { Barnwell } \\
\text { County, SC1 }\end{array}$ & $\begin{array}{c}\text { Barnwell } \\
\text { County, SC2 }\end{array}$ & $\begin{array}{c}\text { Dorchester } \\
\text { County, SC1 }\end{array}$ & $\begin{array}{c}\text { Dorchester } \\
\text { County, SC2 }\end{array}$ \\
\hline 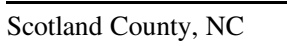 & $\ldots$ & 1.0000 & 1.0000 & 1.0000 & 1.0000 & 1.0000 & 1.0000 \\
\hline Hobbs County, GA & $\ldots$ & $\ldots$ & 1.0000 & 1.0000 & 1.0000 & 1.0000 & 1.0000 \\
\hline Lee County, SC & $\ldots$ & 0.4407 & $\ldots$ & 0.0000 & 0.0000 & 0.0000 & 0.0000 \\
\hline Barnwell County,SC1 & $\ldots$ & 0.3000 & 0.0000 & $\ldots$ & 0.0000 & 0.0000 & 0.0000 \\
\hline Barnwell County, SC2 & $\ldots$ & 0.1892 & 0.0000 & 0.0000 & $\ldots$ & 0.0000 & 0.0000 \\
\hline Dorchester County, SC1 & $\ldots$ & 0.2500 & 0.0000 & 0.0000 & 0.0000 & $\ldots$ & 0.0000 \\
\hline Dorchester County, SC2 & $\ldots$ & 0.8092 & 0.0000 & 0.0000 & 0.0000 & 0.0000 & $\ldots$ \\
\hline
\end{tabular}


H. columbus. Pathogenicity studies could reveal the need to develop different threshold levels for these two Hoplolaimus spp. on soybean. Further research on edaphic factors, mainly studies concerning observations on correlations with soil texture and levels of disturbance, could help predict the presence and distribution of these species. The data presented here on the distribution and genetic variability of $H$. columbus and $H$. stephanus are valuable to growers in determining potentially damaging infestations in fields and to researchers for determining new areas of research emphasis.

\section{Acknowledgments}

Research was supported by the South Carolina Soybean Board Grant Number 2008390

\section{Literature Cited}

Apolônio Silva de Oliveira, D. A., Decraemer, W., Holovachov, O., Burr, J., Tandingan De Ley, I., De Ley, P., Moens, T., and Derycke, S. 2012. An integrative approach to characterize cryptic species in the Thoracostoma trachygaster Hope, 1967 complex (Nematoda: Leptosomatidae). Zool. J. Linn. Soc. 164:18-35.

Appel, J. A., and Lewis, S. A. 1984. Pathogenicity and reproduction of Hoplolaimus columbus and Meloidogyne incognita on Davis soybean. J. Nematol. 16:349-355.

Astudillo, G. E., and Birchfield, W. 1980. Pathology of Hoplolaimus columbus on sugar cane. (Abstr.) Phytopathology 70:565.

Bae, C. H., Robbins, R. T., and Szalanski, A. L. 2009a. Molecular identification of some Hoplolaimus species from the USA based on duplex PCR, multiplex PCR and PCR-RFLP analysis. Nematology 11:471-480.

Bae, C. H., Szalanski, A. L., and Robbins, R. T. 2009b. Genetic variation of Hoplolaimus columbus populations in the United States using PCR-RFLP analysis of nuclear rDNA ITS regions. J. Nematol. 41:201-209.

Castresana, J. 2000. Selection of conserved blocks from multiple alignments for their use in phylogenetic analysis. Mol. Biol. Evol. 17:540-552.

Derycke, S., Remerie, T., Vierstraete, A., Backeljau, T., Vanfleteren, J., Vincx, M., and Moens, T. 2005. Mitochondrial DNA variation and cryptic speciation within the free-living marine nematode Pellioditis marina. Mar. Ecol. Prog. Ser. 300:91-103.

Derycke, S., Van Vynckt, R., Vanoverbeke, J., Vincx, M., and Moens, T. 2007. Colonization patterns of Nematoda on decomposing algae in estuarine environment: Community assembly and genetic structure of the dominant species Pellioditis marina. Limnol. Oceanogr. 52:992-1001.

Donald, P., Holguin, C. M., and Agudelo, P. 2013. First report of lance nematode (Hoplolaimus magnistylus) on corn, soybean, and cotton in Tennessee. Plant Dis. 97:1389.

Excoffier, L., Laval, G., and Schneider, S. 2005. Arlequin ver. 3.0: An integrated software package for population genetics data analysis. Evol. Bioinf. Online 1:47-50.

Fassuliotis, G. 1974. Host range of the Columbia lance nematode Hoplolaimus columbus. Plant Dis. Rep. 58:1000-1002.

Fassuliotis, G., Rau, G. H., and Smith, F. H. 1968. Hoplolaimus columbus, a nematode parasite associated with cotton and soybeans in South Carolina. Plant Dis. Rep. 52:571-572.

Gazaway, W. S., and Armstrong, B. 1994. $1^{\text {st }}$ report of Columbia lance nematode (Hoplolaimus columbus) on cotton in Alabama. Plant Dis. 78:640.

Gutiérrez-Gutiérrez, C., Castillo, P., Cantalapiedra-Navarrete, C., Landa, B. B., Derycke, S., and Palomares-Rius, J. E. 2011. Genetic structure of Xiphinema pachtaicum and $X$. index populations based on mitochondrial DNA variation. Phytopathology 101:1168-1175.

Handoo, Z., and Golden, A. M. 1992. A key and diagnostic compendium to the species of the genus Hoplolaimus Daday, 1905 (Nematoda: Hoplolaimidae). J. Nematol. 24:45-53.

Henn, R. A., and Dunn, R. A. 1989. Reproduction of Hoplolaimus galeatus and growth of seven St. Augustinegrass (Stenotaphrum secundatum) cultivars. Nematropica 19:81-87.

Hugall, A., Moritz, C., Stanton, J., and Wolstenholme, D. R. 1994. Low, but strongly structured mitochondrial DNA diversity in root-knot nematodes (Meloidogyne). Genetics 136:903-912.
Humphreys-Pereira, D. A., and Elling, A. A. 2013. Intraspecific variability and genetic structure in Meloidogyne chitwoodi from the USA. Nematology 15: 315-327.

Huson, D. H., and Bryant, D. 2006. Application of phylogenetic networks in evolutionary studies. Mol. Biol. Evol. 23:254-267.

Jenkins, W. R. 1964. A rapid centrifugal-flotation technique for separating nematodes from soil. Plant Dis. Rep. 48:692.

Kinloch, R. A., and Sprenkel, R. K. 1994. Plant-parasitic nematodes associated with cotton in Florida. J. Nematol. (Suppl.) 26:749-752.

Koenning, S. R., Kirkpatrick, T. L., Starr, J. L., Wrather, J. A., Walker, N. R., and Mueller, J. D. 2004. Plant-parasitic nematodes attacking cotton in the United States: Old and emerging production challenges. Plant Dis. 88:100-113.

Koenning, S. R., Overstreet, C., Noling, J. W., Donald, P. A., Becker, J. O., and Fortnum, B. A. 1999. Survey of crop losses in response to phytoparasitic nematodes in the United States for 1994. J. Nematol. (Suppl.) 31:587-618.

Lewis, S. A., Drye, C. E., Saunders, J. A., Shipe, E. R., and Halbrendt, J. M. 1993 Plant-parasitic nematodes on soybean in South Carolina. J. Nematol. (Suppl.) 25:890-894.

Lewis, S. A., and Fassuliotis, G. 1982. Lance nematodes, Hoplolaimus spp., in the Southern United States. Pages 127-138 in: Nematology in the Southern region of the United States. R. D. Riggs, ed. Southern Co-op Ser. Bull. 276. Arkansas Agric. Exp. Stn., Univ. of Arkansas, Fayetteville, AR.

Lewis, S. A., Smith, F. H., and Powell, W. M. 1976. Host-parasite relationships of Hoplolaimus columbus on cotton and soybean. J. Nematol. 8:141-145.

Librado, P., and Rozas, J. 2009. DnaSP v5: A software for comprehensive analysis of DNA polymorphism data. Bioinformatics 25:1451-1452

Ma, X., Agudelo, P., Mueller, J. D., and Knap, H. T. 2011. Molecular Characterization and Phylogenetic Analysis of Hoplolaimus stephanus. J. Nematol. 43:25-34.

Mueller, J. D., and Sanders, G. B. 1987. Control of Hoplolaimus columbus on lateplanted soybean with aldicarb. J. Nematol. (Suppl.) 19:123-126.

Mueller, J. D., Schmitt, D. P., Weiser, G. C., Shipe, E. R., and Musen, H. L. 1988. Performance of soybean cultivars in Hoplolaimus columbus infested fields J. Nematol. (Suppl.) 20:65-69.

Noe, J. P. 1993. Damage functions and population changes of Hoplolaimus columbus on cotton and soybean. J. Nematol. 25:440-445.

Nyczepir, A. P., and Lewis, S. A. 1979. Relative tolerance of selected soybean cultivars to Hoplolaimus columbus and positive effects of soil temperature. J. Nematol. 11:27-31.

Plantard, O., and Porte, C. 2004. Population genetic structure of the sugar beet cyst nematode Heterodera schachtii: A gonochronistic and amphimictic species with highly inbred but weakly differentiated populations. Mol. Ecol. 13:33-41.

Posada, D., and Crandall, K. A. 1998. MODELTEST: Testing the model of DNA substitution. Bioinformatics 14:817-818.

Robbins, R. T. 1982. Description of Hoplolaimus magnistylus n. sp. (Nematoda: HopIolaimidae). J. Nematol. 14:500-506.

Rodríguez-Kábana, R., and Thurlow, D. L. 1980. Effect of Hoplolaimus galeatus and other nematodes on yield of selected soybean cultivars. Nematropica 10:130-138.

Schmitt, D. P., and Imbriani, J. L. 1987. Management of Hoplolaimus columbus with tolerant soybean and nematicides. J. Nematol. (Suppl.) 19:59-63.

Sher, S. A. 1963. Revision of the Hoplolaiminae (Nematoda) II. Hoplolaimus Daday, 1905 and Aorolaimus N. Gen. Nematol. 9:267-295.

Thompson, J. D., Gibson, T. J., Plewniak, F., Jeanmougin, F., and Higgins, D. G. 1997. The ClustalX windows interface: Flexible strategies for multiple sequence alignment aided by quality analysis tools. Nucleic Acids Res. 25:4876-4882.

Villate, L., Esmenjaud, D., Van Helden, M., Stoeckel, S., and Plantard, O. 2010. Genetic signature of amphimixis allows for the detection and fine scale localization of sexual reproduction events in a mainly parthenogenetic nematode. Mol. Ecol. 19:856-873.

Vovlas, N., Castillo, P., and Gomez, A. 1991. SEM observations on two species of Hoplolaimus Daday, 1905 (Nematoda: Hoplolaimidae). Nematol. Mediterr. 19:305-309. 